2 Joo JB, Cummings AJ. Acute thoracoabdominal aortic dissection presenting as painless, transient paralysis of the lower extremities: case report. J Emerg Med 2000;19:333-7

3 Joseph MG, Langsfield MA, Lusby RJ. Infra-renal aortic aneurysm; unusual cause of paraparesis. Aust NZ J Surg 1989;59:743-4

4 Bolduc ME, Clayson S, Madras PN. Acute aortic thrombosis presenting as painless paraplegia. J Cardiovasc Surg 1989;30:506-8

5 Latif S, Wasti A, Grundy DJ, Isdale A, Iveson JM. Direct erosion of lumbar spine by an abdominal aneurysm resulting in lumbar paralysis: an unusual presentation. Case report. Paraplegia 1995;33:480-1

\section{Puzzling hypercalcaemia: sarcoidosis without lung involvement}

\author{
A Fowler MRCP P Dargan MRCP \\ A Jones FRCP
}

J R Soc Med 2005;98:60-61

In a patient with unexplained hypercalcaemia, sarcoidosis is a possibility even if there is no overt pulmonary disease.

\section{CASE HISTORY}

A Caucasoid woman of 68 was seen after three weeks of confusion, polydipsia, anorexia, general malaise and weight loss. A life-long smoker of ten cigarettes a day, she had no medical history of note. On examination she was cachectic and dehydrated. Nothing else was found - in particular, no rashes, lymphadenopathy, or respiratory or neurological signs. Routine investigations revealed a lymphopenia of $0.6 \times 10^{9} / \mathrm{L}$ (full blood count otherwise normal), erythrocyte sedimentation rate $34 \mathrm{~mm} / \mathrm{h}$, normal serum electrolytes with mild renal impairment (urea $12.1 \mathrm{mmol} / \mathrm{L}$, creatinine $164 \mu \mathrm{mol} / \mathrm{L}$ ) and hypercalcaemia with a corrected serum total calcium of $3.56 \mathrm{mmol} / \mathrm{L}$ and phosphate $1.3 \mathrm{mmol} / \mathrm{L}$; alkaline phosphatase was $165 \mathrm{IU} / \mathrm{L}$, alanine aminotransferase $44 \mathrm{IU} / \mathrm{L}$, gammaglutamyltransferase $81 \mathrm{IU} / \mathrm{L}$, and albumin $30 \mathrm{~g} / \mathrm{L}$. Her chest radiograph was normal.

The initial clinical diagnosis was hypercalcaemia secondary to malignant disease. Further testing revealed a normal mammogram, a normal parathyroid hormone $(\mathrm{PTH})$ of $25 \mathrm{ng} / \mathrm{L}$ (normal range 10-65), parathyroidrelated peptide (PTHrP) $1.0 \mathrm{pmol} / \mathrm{L} \quad(0.1-1.8)$ and 25 -hydroxyvitamin-D $68 \mathrm{nmol} / \mathrm{L}(20-100)$ but a raised

Department of Medicine, St Thomas' Hospital, London SE1 7EH, UK

Correspondence to: Dr A Fowler

E-mail: afowler@doctors.org.uk
1,25-dihydroxyvitamin-D of $144 \mathrm{pmol} / \mathrm{L}$ (20-120). Serum protein electrophoresis was normal and urine examination was negative for Bence Jones protein. After rehydration with intravenous colloid her renal function returned to normal over four weeks. However, she remained symptomatic with a serum calcium concentration of greater than $3.7 \mathrm{mmol} / \mathrm{L}$. She was treated with four intravenous doses of pamidronate $(30 \mathrm{mg}, 60 \mathrm{mg}, 90 \mathrm{mg}, 30 \mathrm{mg}$ ) over eight weeks, during which her calcium peaked at $4.2 \mathrm{mmol} / \mathrm{L}$ (Figure 1).

Abdominal CT revealed minimal dilatation of the left hepatic ducts and portahepatic lymphadenopathy. A CTguided biopsy of these nodes showed non-caseating granulomata. She had a grade zero Heaf test. Highresolution CT of the chest revealed bullous emphysema in the apices but no radiological pulmonary features suggestive of sarcoidosis; however, her serum angiotensin converting enzyme (sACE) was raised at $211 \mathrm{IU} / \mathrm{L}$ (27-82).

Sarcoidosis was diagnosed and she was treated with oral prednisolone $40 \mathrm{mg}$ daily. Symptoms quickly resolved; serum calcium became normal within two weeks and sACE within two months. Twenty months after discharge she was taking $5 \mathrm{mg}$ prednisolone daily and symptom-free; her serum calcium was normal $(2.55 \mathrm{mmol} / \mathrm{L})$.

\section{COMMENT}

Hypercalcaemia, although seen in $10-20 \%$ of patients with sarcoidosis, is rare in the absence of pulmonary involvement. ${ }^{1}$ A search of EMBASE and Medline yielded only ten such cases. The present case illustrates the difficulty of distinguishing between causes of hypercalcaemia. Though not a diagnostic marker of sarcoidosis, a high ACE is a useful pointer. ${ }^{2}$

The mechanism of hypercalcaemia in sarcoidosis is not fully understood. Calcium homoeostasis is controlled mainly by levels of vitamin-D, PTH and calcitonin. 1,25dihydroxycholecalciferol $\left(1,25(\mathrm{OH})_{2} \mathrm{D}_{3}\right)$, the most active form of vitamin-D, is ultimately formed in the kidney following $1 \alpha$-hydroxylation of 25-hydroxycholecalciferol $\left(25[\mathrm{OH}]_{2} \mathrm{D}_{3}\right)$ by the enzyme $1 \alpha$-hydroxylase. $1,25(\mathrm{OH})_{2} \mathrm{D}_{3}$ acts to increase gastrointestinal absorption of calcium and phosphate whilst also stimulating osteoclastmediated bone resorption. ${ }^{3}$ Studies showing increased circulating concentrations of $1,25(\mathrm{OH})_{2} \mathrm{D}_{3}$ in patients with sarcoidosis and hypercalcaemia led to the hypothesis that the cause was related to abnormal vitamin-D metabolism. One theory suggests that increased $1,25(\mathrm{OH})_{2} \mathrm{D}_{3}$ synthesis is caused by activated pulmonary macrophages in granulomatous tissue. ${ }^{1}$ This is validated by studies showing generation of $1,25(\mathrm{OH})_{2} \mathrm{D}_{3}$ from homogenates of alveolar macrophages from patients with sarcoidosis. ${ }^{4}$ Furthermore, an increase in $1 \alpha$-hydroxylase mRNA expression has been 


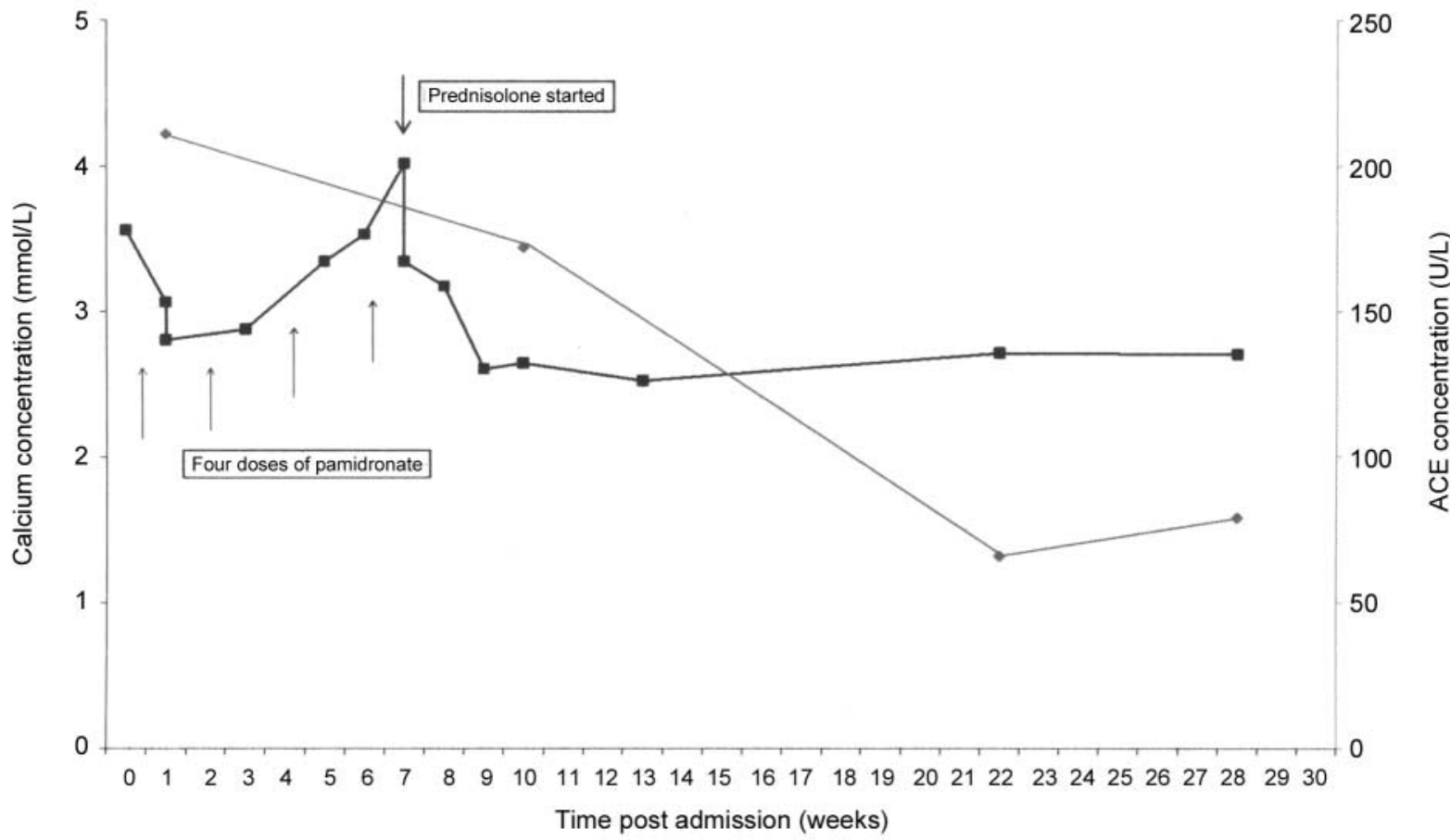

Figure 1 Serum calcium and angiotensin converting enzyme (ACE) concentration and the effect of prednisolone. Serum calcium concentration (mmol/L); serum ACE (IU/L)

reported in alveolar cells obtained from patients with sarcoidosis, with a correlation between expression and disease activity. ${ }^{4}$

If the above theories are correct, hypercalcaemia should not occur in the absence of chest disease. In cases such as ours three possible explanations have been offered. First, the granulomatous tissue responsible for $1,25(\mathrm{OH})_{2} \mathrm{D}_{3}$ production might be below the limits of standard radiographic resolution. ${ }^{1}$ Secondly, the excess $1,25(\mathrm{OH})_{2} \mathrm{D}_{3}$ might originate from extrapulmonary sarcoid granulomatous tissue. Thirdly, hypercalcaemia might be explained by production of PTHrP. PTHrP acts on $1,25(\mathrm{OH})_{2} \mathrm{D}_{3}$ in a similar manner to PTH but is regulated by tumour necrosis factor- $\alpha$ and interleukin- $6 .^{3}$ PTHrP can be found in sarcoid tissue specimens and lymph node homogenates from patients with sarcoidosis ${ }^{3,4}$ and high concentrations have been reported in some patients with sarcoid. The PTHrP was normal in our patient. Finally, there is the possibility that increased $1,25(\mathrm{OH})_{2} \mathrm{D}_{3}$ production may not be the sole cause of hypercalcaemia since $1,25(\mathrm{OH})_{2} \mathrm{D}_{3}$ is not always raised in these patients. ${ }^{4}$

\section{REFERENCES}

1 Sander S, Buller GK, Perazella MA. Hypercalcaemia, sarcoidosis, and normal chest radiographs. Am J Med 1995;99:437-48

2 Adams JS, Gacad MA, Anders A, Enders DB, Sharma OP. Biochemical indicators of disordered vitamin $\mathrm{D}$ and calcium homeostasis in sarcoidosis. Sarcoidosis 1986;3:1-6

3 Conron M, Young C, Beynon H. Calcium metabolism in sarcoidosis and its clinical implications. Rheumatology 2000;39:707-13
4 Gardner DG. Hypercalcaemia and sarcoidosis - another piece of the puzzle falls into place. Am J Med 2001;110:736-7

\section{A diabetic breast lump}

\section{Sanjay A Pai MD $^{1} \quad$ M G Bhat MS FRCS ${ }^{2}$}

J R Soc Med 2005;98:61-62

Organs commonly affected by diabetes mellitus include retina, kidneys and peripheral nerves. Involvement of the breast is unusual.

\section{CASE HISTORY}

A man of 47 sought advice because of below-knee numbness and brief loss of consciousness after a fall from a bicycle. Non-insulin-dependent (type 2) diabetes had been diagnosed 4 years earlier and he was being treated with glibenclamide and metformin. He was also hypertensive.

Departments of ${ }^{1}$ Pathology and ${ }^{2}$ General Surgery, Manipal Hospital, Airport Road, Bangalore 560 017, India

Correspondence to: S A Pai

E-mail: s_pai@vsnl.com 